\title{
RURAL MARKETING-CHALLENGES, STRATEGIES AND OPPORTUNITIES
}

\author{
Dr.P.Suchitra, \\ Professor \& Principal, \\ Sumourya Institute of Mangement, Kurnool \\ svijay1820@gmail.com
}

\begin{abstract}
The Indian rural market has a huge demand base and offers great opportunities to marketers. Two-thirds of Indian population as well prospective consumers live in rural areas and approximately 30\% of India's GNP is generated from rural business segment. Rural markets, as part of Indian economy, have much untapped potential. In recent years, rural markets have acquired enormous significance, as the overall growth of the economy has substantially increased the purchasing power of rural communities. The rural markets are estimated to grow at a faster pace than the urban markets. The potentiality of rural markets is said to be like a 'woken up sleeping giant'. The concept of rural markets in India, as also in several other countries, like China, is still in evolving stage, and the sector poses a variety of challenges, like understanding the dynamics of the rural markets and strategies to supply and satisfy the expectations of rural consumers. On account of green revolution, the rural areas are consuming a large quantity of industrial and urban manufactured products.

Distribution costs and non-availability of retail outlets are some of the major problems faced by the marketers. The success of a brand in the Indian rural market is highly uncertain as some brands, which should have been successful, have failed miserably. Rural markets, have untapped potential but pose difficulties to fully explore rural markets. This paper analyses the emerging trends in the rural marketing sector and emphasizes on the strategies to be adopted by the companies not only for their success but also for their subsequent growth and expansion duly evaluating the market opportunities and taking the right decision to make a mark of itself in this rapidly growing and at the same time highly promising segment.
\end{abstract}

Key Words:-Indian Market,Rural Marketing, Rural population, , RM Challenges, RM Opportunities, RM Strategies

\section{INTRODUCTION}

Marketing is described as the process of defining, anticipating and knowing customer needs and wants, satisfy them and provide the rationale for the firm's existence [1]. Knowledge of consumer behavior, exhibited by individuals, groups and organizations in searching, obtaining, and use of, consumers experience with products and services is vital for a firm to achieve its marketing goals. The rural market of India started showing its potential in the 1960s. The 70s and 80 s witnessed its steady development. And, there are clear indications that the 21st century is going to see its full blossoming. In our country, not much systematized information is available about the rural consumers. Only a few enlightened companies, like HLL, Philips India, Asian Paints, Singer and $\mathrm{L}$ and $\mathrm{T}$ have made concrete efforts in this direction. But, by and large, we have still to understand the rural buyer, his habits, attitudes and behaviour, particularly from the marketing point of view. Many assumptions prevail about rural marketing, like rural buyer is not very discriminating. And can be persuaded to buy but in reality, he being suspicious of the marketer's hard sell techniques, is quite discriminating, and is not easily persuaded. Yet another assumption is that the rural buyer is not particularly keen about quality and packaging but not true. 


\section{Concept of Rural Marketing}

The term 'rural marketing' used to be an umbrella term for the people who dealt with rural people in one way or other. Rural marketing referred to selling of rural products and agricultural inputs in rural markets. It was treated as synonymous to 'agricultural marketing'. This term got a separate meaning and importance after the economic revaluation in Indian after 1990.

Rural marketing broadly is used to identify, understand, and satisfy the rural customer thereby increase sale of goods and services. In pre-1960's rural marketing was identical with agricultural marketing. From 1960's to1990's, the marketing of agriculture input and marketing of non-farm rural product was considered as rural marketing. Post 1990s due to rise in income various companies focused on tapping rural market potential. Now rural marketing refers to FMGC and consumer durable goods in rural area [2]. Indian rural marketing can be classified into different categories:-

_ Urban to Rural- refers to the selling of products and services by urban marketers in rural areas like Pesticides, Tractors, FMCG Products, Consumer durables etc.

_ Rural to Urban- involves a rural producer selling his products like fruits, vegetables, grains, pulses, spices etc. in urban market through middlemen, agencies, government co-operatives.

Rural to Rural- include the selling of agricultural tools, cattle and carts by villagers in its proximity.

Though interdependent, rural and urban markets adopt different strategies because

-In an urban market customers are more aware, standard of living are higher and customer are more demanding and vice versa.
- In rural market customers standard of living is less, more price sensitive, brand awareness and brand recognition and product choice and options are less in the rural markets than in urban markets.[3]The economic reforms, liberalization and globalization of the Indian economy have added advantage to sophisticated production, proliferation and mass distribution of goods and services. Indian rural market is almost twice as large as the entire market of the USA or that of the USSR.

\subsection{Characteristics' of Rural Market}

- Large and Scattered Market over 73 percent consumers from 6.36 lakhs villages.

- Major Source of Income is from Agriculture Sector which results in disguised and seasonal unemployment, and also less growth of industrial sector.

- Socio Economical Backwardness of Rural consumers and low standard of living.

- Conservative Outlook-consumers reluctant to change their old customs and traditions.

- High Illiteracy - because of lack of education facilities.

- Lack of Financial and infrastructural Facilities as per requirement of rural areas.

- Initiatives by Government- schemes and grants have been implemented by government to improve the conditions and increase employment opportunities in rural sector

Rural marketing process is both a catalyst as well as an outcome of the general rural development process. Initiation and management of social and economic change 
in the rural sector is the core of the rural marketing process.

\subsection{Why go Rural}

The growth of any economy largely depends upon the growth of the rural population. Gandhi said,' India lives in her several hundred of villages'. The Mckinsey Report (2007) makes above statement true because

TABLE 1: Population of India and occupa

\begin{tabular}{|c|c|c|c|c|c|}
\hline \multicolumn{6}{|c|}{ Population in crores } \\
\hline & \multirow[t]{2}{*}{1981} & \multirow[t]{2}{*}{1991} & \multirow[t]{2}{*}{2001} & \multicolumn{2}{|c|}{$\begin{array}{l}\text { Increase over previous } \\
\text { decade }\end{array}$} \\
\hline & & & & 1991 & 2001 \\
\hline Rural & 50.20 & 60.21 & 66.0 & +10.01 & +5.79 \\
\hline Urban & 15.62 & 24.18 & 32.6 & +8.56 & +8.42 \\
\hline Total & 65.82 & 84.39 & 98.6 & 18.57 & 14.21 \\
\hline
\end{tabular}

Source: Census of India, 2001 (P)[4]

Around 70 percent of the total population live in the rural areas that provide a larger market compared to the urban market. according to this report, "In 20 years the rural Indian market will be larger than the total consumer markets in countries such as South Korea today and almost four times the size of today's urban India market. It is estimated that the size of rural market will be USD 577 billion"

\begin{tabular}{|l}
\hline TABLE 2:Literacy levels (in percentage) \\
\begin{tabular}{|l|l|l|l|l|}
\hline Gender & 1981 & 1991 \\
\cline { 2 - 5 } & Rural & Urban & Rural & Urban \\
\hline Males & 41 & 66 & 58 & 81 \\
\hline Females & 18 & 43 & 31 & 64 \\
\hline Total & 30 & 57 & 45 & 73 \\
\hline
\end{tabular}
\end{tabular}

Source: Census of India, 1991.[4] Only 45 per cent of the total rural population are literate as compared to 73 per cent in urban areas. The literacy plays a pivotal role in designing the communication strategy for rural folks.

TABLE 3: Income generation in rural areas
\begin{tabular}{|l|l|l|}
\hline Sr. no & Source of income & Proportionto total \\
\hline 1 & Agriculture & 58.8 \\
\hline 2 & Agricultural wages & 16.1 \\
\hline 3 & Business and crafts & 8.8 \\
\hline 4 & $\begin{array}{l}\text { Non-agricultural } \\
\text { wages }\end{array}$ & 7.2 \\
\hline 5 & Salaries & 2.5 \\
\hline 6 & Current transfers & 1.9 \\
\hline 7 & Others & 4.7 \\
\hline Total & & 100 \\
\hline
\end{tabular}

Source: G.M. Pande- Rural Marketing, Thrust and Challenge, p. 30.[5]

Nearly 75 per cent of the total income in rural areas is agriculture based leading to rural prosperity and provides a great potential for the marketers.

Source: T.P. Gopalaswamy- Environment, Problem and strategies.[6] 
2.3 Rural marketing involve a number of strategies, which include:

1. Client and Location specific promotion strategy suitable to the location and the client.

2. Joint or co-operative promotion strategy between the marketing agencies and the client.

3. 'Bundling of inputs' marketing strategy, in which several related items are sold to the target client, including arrangements of credit, after-sale service, and so on.

4. Developmental marketing and Unique Selling Proposition(USP) to attract and make them buy 5 . Media, both traditional as well as the modern media, is used as a marketing strategy.

6. Unique Selling Propositions (USP) involves presenting a theme with the product to attract the client to buy that particular product.

7. Extension Services, attending to the missing links and providing the required know-how.

8. Ethics in Business and Partnership for sustainability.

\subsection{Challenges in Rural Marketing}

India is ingenious with a good degree of ethnic, cultural and regional diversity. In India, Rural market has a high demand that contributes more profit than urban . Now days companies are adopting the mix of 4A's strategy that affordability, awareness, availability and acceptability in place of 4P's strategy ie product, price, place (distribution) and promotion. Though 4P's are the more challengeablein the rural market, it is not easy to enter the rural market because of
Low Literacy as low (36\%)when compared to all-India average of $52 \%$, due to lack of education

Seasonal Demand: Demand for goods in rural markets depends upon agricultural production.

Transportation and Communication problems due to which villages are isolated Distribution An effective distribution system requires village-level shopkeeper, Mandal/ Taluka- level wholesaler or preferred dealer, distributor or stockiest at district level.

Traditional Life in rural areas still governed by old customs and traditions.

Buying Decisions Rural consumers are cautious in buying and decisions are slow and delayed.

Media for Promotions Radio and Television have made a great impact and large audience has been exposed to this medium at low cost.

\subsection{Emerging trends in markets:}

$>$ Online rural market (internet, nicenet): for getting information and also online selling.

$>$ Information through local agriculture input dealers:regarding awareness about pests, diseases, fertilizers, seeds, technology and the like

$>$ Cost benefit analysis: facilitated by development of IT at the doorsteps of villagers which results in need based production and creates global village.

Market driven agricultural extension,increasing demand for Processing industry and Rural agriexport that have the potential market in Asian, Europe and western countries. 
ELK

Asia Pacific Journals

\subsection{Recommendations}

Companies have to develop and define value for new products that fulfill the unique needs as well as value of its durability, affordability and multiple uses.To be successful companies have to

$\checkmark$ Communicate in local language for promoting their products.

$\checkmark$ Understand the cultural and social values of the rural people.

$\checkmark$ Generate product awareness ,develop rural specific products and distribute them effectively by using non-conventional and interactive medias.

$\checkmark$ Make investment in transportation, warehousing, infrastructure to get long term benefits.

$\checkmark$ Replace middleman and train rural youth in computers and English language to overcome the cost and reduce administrative problems.

\section{CONCLUSION}

The rural market of India is not only fascinating and challenging but also offers large scope for expansion and development. Being less competitive, it is attractive as a small growth can push up the sales of a product substantially. Economic reforms in India have made rural marketing an important playground for marketers. Successful rural marketing calls for a review of environment, developing proper understanding of the nature and profile of rural consumers, designing the right products to appeal to them, and adopting suitable media as well as appropriate strategies for communication and distribution. Rural markets are created and it is a market for the truly creative marketer in India.
ELK Asia Pacific Journals - Special Issue

ISBN: 978-81-930411-9-2

\section{REFERENCES}

[1] Kotler, Philip, "Marketing Management-Analysis, planning, implementation and control", Prentice Hall of India, $9^{\text {th }}$ edition, 1997.

[2] Bijoor, Harish, "Go Rural", Economic Times, June 14, 1999.

[3] www.blurtit.com; www.wikianswers.com; www.csisigegov.org).

[4] Census of India, 1991 and 2001.

[5] Pande.K., "New Perspective in Marketing", Rural Marketing: Thrust and Challenges, National Publishing House, New Delhi, 1997.

[6] Gopalaswamy, T.P., "Environment, Problems, and Strategies", Wheeler Publishing, New Delhi, 1997. 